\title{
Mannich-Type Reactions of Aldimines and Hetero Diels-Alder Reactions of Aldehydes Catalyzed by Anion-Type Lewis Bases Derived from a Single Molecule
}

\author{
Kaori Ishimaru*, Daiki Maeda, Kaori Ono, Yuya Tanimura \\ Department of Chemistry, National Defense Academy, Yokosuka, Japan \\ Email: *kaoriisi@nda.ac.jp
}

Received July 31, 2012; revised August 30, 2012; accepted September 8, 2012

\begin{abstract}
Mannich-type reactions of aldimines with silyl enolates and hetero Diels-Alder reactions of aldehydes with Danishefsky's diene in the presence of anion catalysts derived from proline were performed to afford the corresponding products in high yields.
\end{abstract}

Keywords: Anion Catalyst; Lewis Base; Proline; Mannich-Type Reaction; Hetero Diels-Alder Reaction

\section{Introduction}

Organocatalytic reactions using natural amino acids such as proline or its derivatives have recently received much attention in organic synthesis [1-9].Despite the many reports on proline-derived catalysts, the generation of iminium ions or enamine intermediates was necessary in most reactions [10-30]. Unlike these catalysts, we envisioned that anion-type Lewis base catalysts (Scheme 1) prepared from a single molecule, i.e., proline, would have a wide range of Lewis basicities and activate the various silyloxy compounds.

Yamaguchi et al. have first reported the enantioselective Michael addition of a simple malonate to enones and enals in the presence of rubidium salt of proline [31-34]. Recent reports have shown that the simple anion catalysts were useful for various reactions [35-50] including Mannich-type reactions [51-55] and hetero Diels-Alder reactions [56]. The combination of proline and amine also has been developed [57-58], however, the anioncatalyzed reactions using proline-derivedcompounds are still challenging. Here we report two different reactions (the Mannich-type reactions and hetero Diels-Alder reactions) using the anion-type Lewis base catalysts derived from a single molecule.

\section{Results and Discussion}

\subsection{Mannich-Type Reactions of Aldimines}

We first prepared various proline-derived compounds1a$1 \mathrm{c}$ according to the literature [59-61]. In our initial stud-

${ }^{*}$ Corresponding author. ies, the Mannich-type reaction of aldimine 2a and silyl enolate 3a was performed in DMF solution using lithium salt of 1a as a Lewis base catalyst which was prepared from 1a and MeLi in THF [50] just before use (Table 1). The use of $25 \mathrm{~mol} \%$ of $1 \mathrm{a}$ and $25 \mathrm{~mol} \%$ of MeLi resulted in low yields of the corresponding $\beta$-amino ester $4 \mathrm{a}$ (entry 1 in Table 1). Since a small excess of MeLi would decompose the product, 0.5 equiv of MeLi relative to the proline-derived compound was used for the reaction (entries 2 - 6). We found that $2.5 \mathrm{~mol} \%$ of Lewis base derived from $1 \mathrm{~b}$ was effective to afford the corresponding $\beta$-amino ester in $74 \%$ yield (entry 5). However, attempt to use aldimine $2 \mathrm{e}$ having $p$-chlorophenyl group gave $<20 \%$ yield of the product under the same conditions,

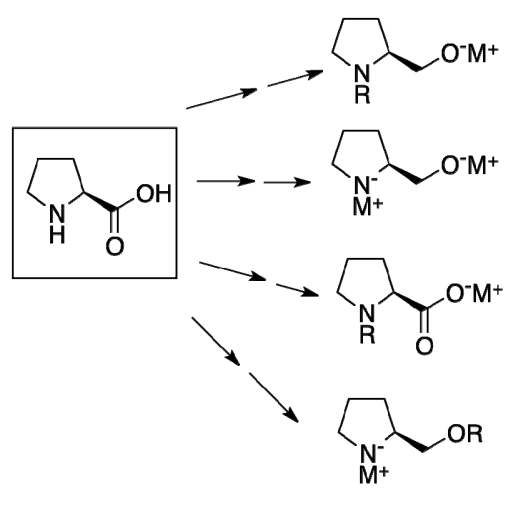

various anion-type Lewis base catalysts

Scheme 1. Anion-type Lewis base catalysts derived from a single molecule. 
Table 1. Mannich-type reaction of aldimine $2 a$ and silyl enolate $3 a$ in the presence of Lewis base catalysts ${ }^{a}$.

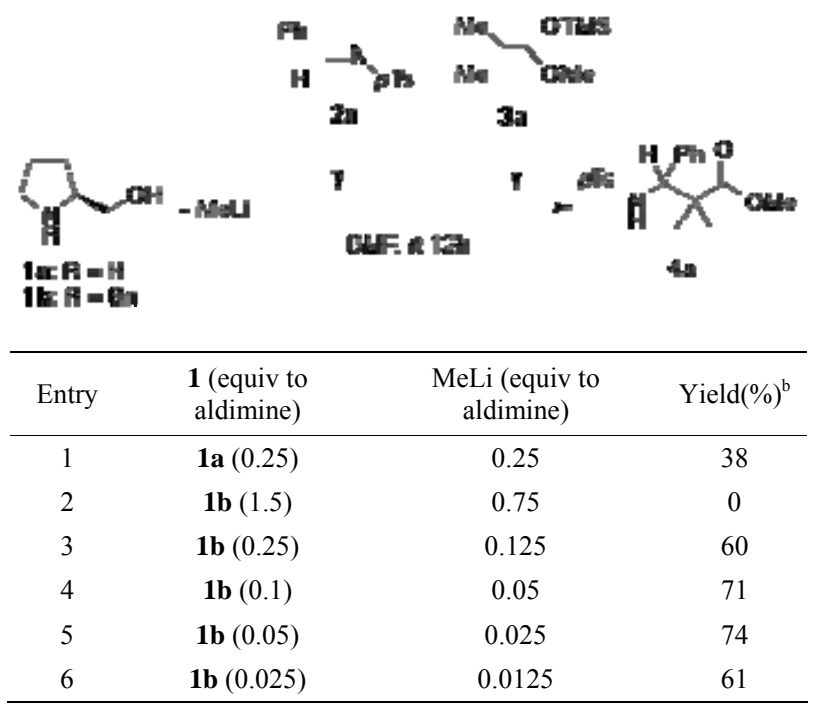

a: Reaction conditions: aldimine ( $1 \mathrm{mmol})$, silyl enolate $(1.5 \mathrm{mmol})$ in DMF $(2 \mathrm{ml})$. Reactions were carried out at $\mathrm{rt}$ for $12 \mathrm{~h}$; b: Isolated yields after column chromatography.

indicating that the reaction depended on the substituent of the aldimines. After some experiments, $30 \mathrm{~mol} \%$ of the anion catalyst $1 \mathrm{c}$ in the reaction of $2 \mathrm{a}$ with $3 \mathrm{a}$ also gave a high yield of the product $4 \mathrm{a}$ (entry 1 in Table 2). Under these optimized conditions, the Mannich-type reactions of various aldimines $(2 \mathrm{~b}-2 \mathrm{e})$ were carried out (entries 2 - 5). To our delight, the reaction of $2 \mathrm{e}$ also proceeded in high yield (entry 5). Electron-poor (entries 4 and 5) and electron-rich (entry 2) aromatic aldehydes reacted with equal facility. We also carried out the reaction with $3 \mathrm{~b}$ having a phenyl group to afford corresponding $\beta$-amino esters in high yields (entries $6-8$ in Table 2).

\subsection{Hetero Diels-Alder Reactions of Aromatic Aldehydes}

With these results in hand, we next examined the hetero Diels-Alder reaction of aromatic aldehyde and Danishefsky's diene (Table 3) using the anion-type catalysts derived from the same molecule (proline), in which the substrates were quite different from those in Mannich-type reactions. After some experiments, the anion catalyst prepared from $1 \mathrm{~b}$ and $\mathrm{BuLi}$ was suitable for the reaction. We found that $20 \mathrm{~mol} \%$ of the catalyst promoted the reaction of benzaldehyde in $84 \%$ yield (entry 1 ), however, the low yield was observed with $o$-tolualdehyde. Additional experiments were performed and the use of $30 \mathrm{~mol} \%$ of the catalyst has been successfully applied for the substituted benzaldehydes (entries $2-5)$. The reaction of $p$-anisaldehyde having an electron-donating group gave moderate yield of the product
Table 2. Mannich-type reactions of aldimines with silyl enolates in the presence of Lewis base catalyst derived from $1 c^{a}$.

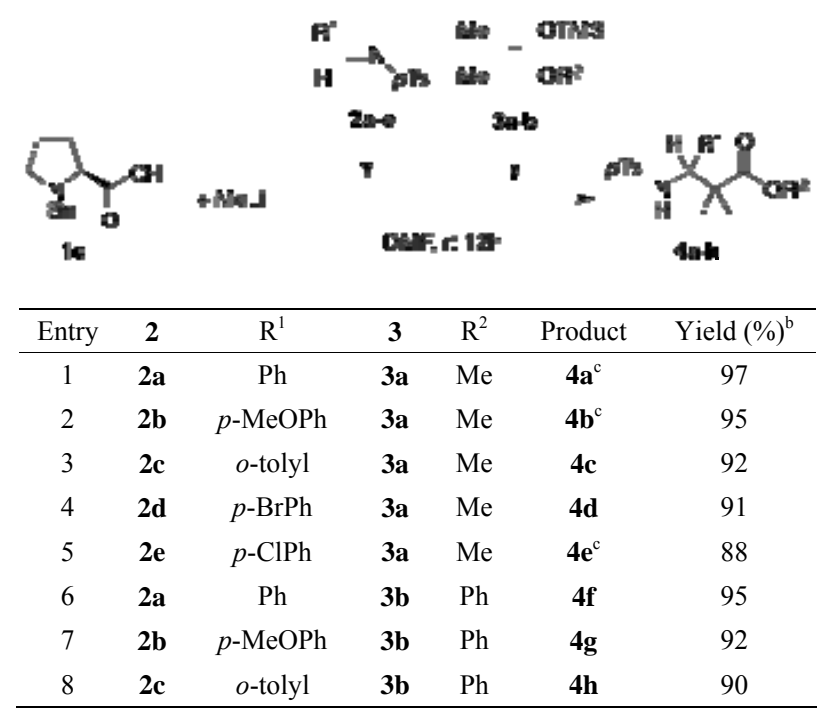

a: Reaction conditions: anion catalyst $(0.3 \mathrm{mmol})$, aldimine $(1 \mathrm{mmol})$, silyl enolate $(1.5 \mathrm{mmol})$ in DMF $(2 \mathrm{ml})$. Reactions were carried out at $\mathrm{rt}$ for $12 \mathrm{~h}$; b: Isolated yields after column chromatography; c: The spectral data were consistent with those in ref 55.

Table 3. Hetero diels-alder reactions of aromatic aldehydes with danishefsky's diene ${ }^{a}$.

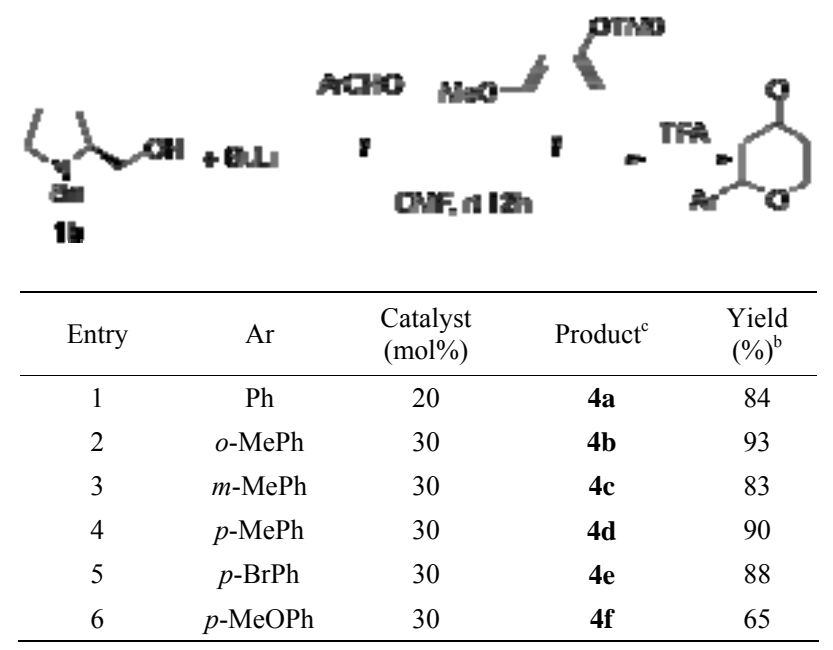

a: Reaction conditions: aldehyde $(0.5 \mathrm{mmol})$, Danishefsky's diene (1.0 $\mathrm{mmol}$ ) in DMF (total $3 \mathrm{ml}$ ). Reactions were carried out at $\mathrm{rt}$ for $12 \mathrm{~h}$; b: Isolated yields after column chromatography; c: The spectral data of the products were consistent with that in ref. [62] for $4 \mathrm{c}$ and $4 \mathrm{e}$, ref. [63] for $4 \mathrm{a}$, $4 \mathrm{~d}$, and $4 \mathrm{f}$, and ref. [64] for $4 \mathrm{~b}$.

(entry 6). In all cases, addition of water resulted in low yields of products with starting materials.

\section{Conclusion}

In conclusion, Mannich-type reactions of aldimines with silyl enolates and hetero Diels-Alder reactions of aldehydes in the presence of anion catalysts derived from 
proline were performed to afford the corresponding products in high yields. Further applications using the various anions of the proline are now in progress.

\section{Experimental}

\subsection{General}

All reactions were carried out under an inert atmosphere and in dried glassware. Anhydrous THF and DMF were used for the all reactions. Flash column chromatography was performed on silica gel (particle size $0.063-0.200$ mm, Merck silica gel 60). The ${ }^{1} \mathrm{H}$ NMR spectra were recorded with a JEOL JNM-AL300 BK1 spectrometer at $300 \mathrm{MHz}$ with chemical shift values (d) reported in ppm relative to an internal standard (TMS). High resolution mass spectra were measured with a JEOL SX-102A spectrometer.

\subsection{Typical Experimental Procedure for Mannich-Type Reactions}

\subsubsection{General Procedure for Preparation of $N$-Benzylproline Lithium Salt.}

To a stirred solution of $1 \mathrm{c}(0.64 \mathrm{~g}, 3.1 \mathrm{mmol})$ in THF (25 $\mathrm{ml})$ was slowly added $1.55 \mathrm{mmol}$ of MeLi (1.09 M diethylether solution) at $0^{\circ} \mathrm{C}$ under Ar. The reaction mixture was stirred at $30^{\circ} \mathrm{C}$ for $20 \mathrm{~min}$ and cooled to r.t. The catalyst solution was used without further purification.

\subsubsection{General Procedure for Mannich-Type Reactions} The catalyst solution prepared as mentioned above (5.1 $\mathrm{ml}, 0.3 \mathrm{mmol}$ ) was transferred to a two-necked flask, and THF was evaporated in vacuo. Dry DMF $(1 \mathrm{ml})$ was added to the flask, and $1 \mathrm{mmol}$ of aldimine in dry DMF $(1 \mathrm{ml})$ and silyl enolate $(1.5 \mathrm{mmol})$ were added successively at r.t. The reaction mixture was stirred at r.t. for 12 $\mathrm{h}$, and quenched with saturated aqueous $\mathrm{NH}_{4} \mathrm{Cl}$. The mixture was extracted with AcOEt, and the organic layers were dried over sodium sulfate. After filtration, the solvent was evaporated to give the crude product. The crude product was purified by flash column chromatography (hexane:EtOAc: $\mathrm{CH}_{2} \mathrm{Cl}_{2}=3: 1: 1$ ).

\subsection{Identification of the Products}

Methyl 2,2-Dimethyl-3-(2-tolyl)-3-(tosylamino) propanoate (4c). Colorless oil; ${ }^{1} \mathrm{H}$ NMR (300 MHz, $\mathrm{CDCl}_{3}$ ) $\delta=1.06(\mathrm{~s}, 3 \mathrm{H}), 1.35(\mathrm{~s}, 3 \mathrm{H}), 2.27(\mathrm{~s}, 6 \mathrm{H}), 3.65(\mathrm{~s}, 3 \mathrm{H})$ $4.72(\mathrm{~d}, 1 \mathrm{H}, J=9.2 \mathrm{~Hz}), 6.24(\mathrm{~d}, 1 \mathrm{H}, J=9.2 \mathrm{~Hz}), 6.82-$ $6.99(\mathrm{~m}, 6 \mathrm{H}), 7.27$ - $7.35(\mathrm{~m}, 2 \mathrm{H})$; HRMS-FAB(M + $\mathrm{H})^{+} m / z$ calcd for $\mathrm{C}_{20} \mathrm{H}_{26} \mathrm{O}_{4} \mathrm{NS} 376.1599$, found 376.1663.

Methyl 3-(4-Bromophenyl)-2,2-dimethyl-3-(tosylamino) propanoate (4d). Colorless oil; ${ }^{1} \mathrm{H}$ NMR (300 $\left.\mathrm{MHz}, \mathrm{CDCl}_{3}\right) \delta=1.06(\mathrm{~s}, 3 \mathrm{H}), 1.31(\mathrm{~s}, 3 \mathrm{H}), 2.33(\mathrm{~s}, 3 \mathrm{H})$, $3.61(\mathrm{~s}, 3 \mathrm{H}), 4.31(\mathrm{~d}, 1 \mathrm{H}, J=9.5 \mathrm{~Hz}), 6.27(\mathrm{~d}, 1 \mathrm{H}, J=9.5$
$\mathrm{Hz}), 6.77(\mathrm{~d}, 2 \mathrm{H}, J=8.4 \mathrm{~Hz}), 7.00(\mathrm{~d}, 2 \mathrm{H}, J=8.1 \mathrm{~Hz})$, 7.13 - $7.16(\mathrm{~m}, 2 \mathrm{H}), 7.38$ (d, 2H, $J=8.4 \mathrm{~Hz}$ ); HRMS$\mathrm{FAB}(\mathrm{M}+\mathrm{H})^{+} m / z$ calcd for $\mathrm{C}_{19} \mathrm{H}_{23} \mathrm{O}_{4} \mathrm{NSBr} 440.0549$, found 440.0560.

Phenyl 2,2-Dimethyl-3-phenyl-3-(tosylamino) propanoate (4f). Colorless oil; ${ }^{1} \mathrm{H} \mathrm{NMR}\left(300 \mathrm{MHz}, \mathrm{CDCl}_{3}\right.$ ) $\delta=1.17(\mathrm{~s}, 3 \mathrm{H}), 1.36(\mathrm{~s}, 3 \mathrm{H}), 2.16(\mathrm{~s}, 3 \mathrm{H}), 4.54(\mathrm{~d}, 1 \mathrm{H}, J$ $=10.3 \mathrm{~Hz}), 6.18(\mathrm{~d}, 1 \mathrm{H}, J=10.3 \mathrm{~Hz}), 6.80-7.32(\mathrm{~m}$, $14 \mathrm{H})$; HRMS-FAB(M+H) ${ }^{+} m / z$ calcd for $\mathrm{C}_{24} \mathrm{H}_{26} \mathrm{O}_{4} \mathrm{NS}$ 424.1599, found 424.1614.

Phenyl 3-(4-Methoxyphenyl)-2,2-dimethyl-3- (tosylamino)propanoate (4g). Colorless oil; ${ }^{1} \mathrm{H}$ NMR (300 $\left.\mathrm{MHz}, \mathrm{CDCl}_{3}\right) \delta=1.16(\mathrm{~s}, 3 \mathrm{H}), 1.27(\mathrm{~s}, 3 \mathrm{H}), 2.15(\mathrm{~s}, 3 \mathrm{H})$, $3.62(\mathrm{~s}, 3 \mathrm{H}), 4.57(\mathrm{~d}, 1 \mathrm{H}, J=10.4 \mathrm{~Hz}), 6.36(\mathrm{~d}, 1 \mathrm{H}, J=$ $10.4 \mathrm{~Hz}), 6.44-6.45(\mathrm{~m}, 2 \mathrm{H}), 6.47-6.48(\mathrm{~m}, 4 \mathrm{H})$, 6.94-6.95 (m, 2H), 7.13 - $7.17(\mathrm{~m}, 1 \mathrm{H}), 7.23$ - $7.34(\mathrm{~m}$, $4 \mathrm{H}) ; \quad \mathrm{HRMS}-\mathrm{FAB}(\mathrm{M}+\mathrm{H})^{+} m / z$ calcd for $\mathrm{C}_{25} \mathrm{H}_{28} \mathrm{O}_{5} \mathrm{NS}$ 454.1705, found 454.1723.

Phenyl 2,2-Dimethyl-3-(2-tolyl)-3-(tosylamino)propanoate (4h). Colorless oil; ${ }^{1} \mathrm{H}$ NMR (300 MHz, $\left.\mathrm{CDCl}_{3}\right)$ $\delta=1.23(\mathrm{~s}, 3 \mathrm{H}), 1.46(\mathrm{~s}, 3 \mathrm{H}), 2.23(\mathrm{~s}, 3 \mathrm{H}), 2.31(\mathrm{~s}, 3 \mathrm{H})$, $4.99(\mathrm{~d}, 1 \mathrm{H}, J=9.8 \mathrm{~Hz}), 6.29$ (d, 1H, $J=9.8 \mathrm{~Hz}), 6.85$ $7.03(\mathrm{~m}, 8 \mathrm{H}), 7.21$ - $7.40(\mathrm{~m}, 5 \mathrm{H})$; HRMS-FAB $(\mathrm{M}+\mathrm{H})^{+}$ $m / z$ calcd for $\mathrm{C}_{25} \mathrm{H}_{28} \mathrm{O}_{4} \mathrm{NS}$ 438.1756, found 438.1764 .

\subsection{Typical Experimental Procedure for Hetero Diels-Alder Reactions}

\subsubsection{General Procedure for Preparation of Anion Catalysts for Hetero Diels-Alder Reaction}

To a stirred solution of $1 \mathrm{~b}(0.17 \mathrm{~g}, 0.9 \mathrm{mmol})$ in THF (2 $\mathrm{ml}$ ) was slowly added $0.45 \mathrm{mmol}$ of $n$-BuLi (1.6 M $n$ hexane solution) at $0^{\circ} \mathrm{C}$ under Ar. The reaction mixture was stirred at r.t. for $15 \mathrm{~min}$ and the solvent was evaporated in vacuo. Dry DMF $(3 \mathrm{ml})$ was added to the flask under Ar, and the catalyst solution was used without further purification.

\subsubsection{General Procedure for Hetero Diels-Alder Reactions}

The catalyst solution prepared as mentioned above $(1 \mathrm{ml}$, $0.15 \mathrm{mmol}$ ) was transferred to a two-necked flask under Ar. To the stirred solution, DMF $(2 \mathrm{ml}), 0.5 \mathrm{mmol}$ of aldehyde and Danishefsky's diene $(1 \mathrm{mmol})$ were added successively at r.t. The reaction mixture was stirred at r.t. for $12 \mathrm{~h}$, and quenched with saturated aqueous $\mathrm{NH}_{4} \mathrm{Cl}$. The mixture was extracted with AcOEt, and the organic layers were washed with water and brine, and dried over sodium sulfate. After filtration, the solvent was evaporated. To the crude mixture, diethylether $(5 \mathrm{ml})$ and trifluoroacetic acid $(0.45 \mathrm{ml})$ were added. The reaction mixture was stirred at r.t. for $15 \mathrm{~min}$ and quenched with saturated aqueous $\mathrm{NaHCO}_{3}$. The mixture was extracted with AcOEt and the organic layers were dried over so- 
dium sulfate. After filtration, the solvent was evaporated to give the crude product. The crude product was purified by flash column chromatography (hexane:EtOAc $=10: 1$ ). The spectral data of the products were consistent with that in ref. [62] for $4 \mathrm{c}$ and $4 \mathrm{e}$, ref. [63] for $4 \mathrm{a}, 4 \mathrm{~d}$, and $4 \mathrm{f}$, and ref. [64] for $4 \mathrm{~b}$.

\section{REFERENCES}

[1] G. Guillena, C. Nájera and D. J. Ramón, "Enantioselective Direct Aldol Reaction: The Blossoming of Modern Organocatalysis," Tetrahedron: Asymmetry, Vol. 18, No. 19, 2007, pp. 2249-2293. doi:10.1016/j.tetasy.2007.09.025

[2] A.Ting and S. E. Schaus, "Organocatalytic Asymmetric Mannich Reactions: New Methodology, Catalyst Design, and Synthetic Applications," European Journal of Organic Chemistry, Vol. 2007, No. 35, 2007, pp. 5797-5815. doi:10.1002/ejoc.200700409

[3] H. Kotsuki, H. Ikishima and A. Okuyama, "Organocatalytic Asymmetric Synthesis Using Proline and Related Molecules. Part 1," Heterocycles, Vol. 75, No. 3, 2008, pp. 493-529. doi:10.3987/REV-07-620

[4] H. Kotsuki, H. Ikishima and A. Okuyama, "Organocatalytic Asymmetric Synthesis Using Proline and Related Molecules. Part 2," Heterocycles, Vol. 75, No. 4, 2008, pp. 757-797. doi:10.3987/REV-07-621

[5] P. Melchiorre, M. Marigo, A. Carlone and G. Bartoli, "Asymmetric Aminocatalysis - Gold Rush in Organic Chemistry," Angewandte Chemie International Edition, Vol. 47, No. 33, 2008, pp. 6138-6171. doi:10.1002/anie.200705523

[6] M. Gruttadauria, F. Giacalone and R. Noto, "Supported proline and proline-derivatives as recyclable organocatalysts," Chemical Society Reviews, Vol. 37, No. 8, 2008, pp. 1666-1688. doi:10.1039/b800704g

[7] A.-N. Alba, X. Companyó, M. Viciao and R. Rios, "Organocatalytic Domino Reactions," Current Organic Chemistry, Vol. 13, No. 14, 2009, pp. 1432-1474. doi:10.2174/138527209789055054

[8] Š. Toma, M. Mečiarová, R. Šebesta, "Are Ionic Liquids Suitable Media for Organocatalytic Reactions?" European Journal of Organic Chemistry, Vol. 2009, No. 3, 2009, pp. 321-327. doi:10.1002/ejoc.200800809

[9] H. Pellissier, "Asymmetric Organocatalytic Cycloadditions," Tetrahedron, Vol. 68, No. 10, 2012, pp. 21972232. doi:10.1016/j.tet.2011.10.103

[10] B. Simmons, A. M. Walji and D. W. C. MacMillian, "Cycle-Specific Organocascade Catalysis: Application to Olefin Hydroamination, Hydro-oxidation, and Aminooxidation, and to Natural Product Synthesis," Angewandte Chemie International Edition, Vol. 48, No. 24, 2009, pp. 4349-4353. doi:10.1002/anie.200900220

[11] C. Chandler, P. Galzerano, A. Michrowska and B. List, "The Proline-Catalyzed Double Mannich Reaction of Acetaldehyde with $\mathrm{N}$-Boc Imines," Angewandte Chemie International Edition, Vol. 48, No. 11, 2009, pp. 19781980. doi:10.1002/anie.2008060s49

[12] S. Chercheja, T. Rothenbücher and P. Eilbracht, "Tandem
Metal and Organocatalysis in Sequential Hydroformylation and Enantioselective Mannich Reactions," A Advanced Synthesis \& Catalysis, Vol. 351, No. 3, 2009, pp. 339-344. doi:10.1002/adsc. 200800720

[13] A. Odedra and P. H. Seeberger, "5-(Pyrrolidin-2-yl)tetrazole-Catalyzed Aldol and Mannich Reactions: Acceleration and Lower Catalyst Loading in a ContinuousFlow Reactor," Angewandte Chemie International Edition, Vol. 48, No. 15, 2009, pp. 2699-2702. doi:10.1002/anie.200804407

[14] X. Ding, H.-L. Jiang, C.-J. Zhu and Y.-X. Cheng, "Direct Asymmetric $\alpha$-Amination of Aldehydes with azodicarboxylates in Ionic Liquids Catalyzed by Imidazolium IonTagged Proline Organocatalyst," Tetrahedron Letters, Vol. 51, No. 47, 2010, pp. 6105-6107. doi:10.1016/j.tetlet.2010.09.036

[15] V. Rawat, P. V. Chouthaiwale, V. B. Chavan, G. Suryavanshi and A. Sudalai, "A Facile Enantioselective Synthesis of $(S)-N$-(5-Chlorothiophene-2-sulfonyl)- $\beta, \beta$-diethyla-laninol via Proline-Catalyzed Asymmetric $\alpha$-Aminooxylation and $\alpha$-Amination of Aldehyde," Tetrahedron Letters, Vol. 51, No. 50, 2010, pp. 6565-6567. doi:10.1016/j.tetlet.2010.10.029

[16] F. Kelleher, S. Kelly, J. Watts and V. McKee, "Structure-Reactivity Relationships of $L$-Proline Derived Spirolactams and $\alpha$-Methyl Prolinamide Organocatalysts in the Asymmetric Michael Addition Reaction of Aldehydes to Nitroolefins," Tetrahedron, Vol. 66, No. 19, 2010, pp. 3525-3536. doi:10.1016/j.tet.2010.03.002

[17] W.-H. Wang, T. Abe, X.-B. Wang, K. Kodama, T. Hirose and G.-Y. Zhang, "Self-Assembled Proline-Amino Thioureas as Efficient Organocatalysts for the Asymmetric Michael Addition of Aldehydes to Nitroolefins," Tetrahedron: Asymmetry, Vol. 21, No. 24, 2010, pp. 29252933. doi:10.1016/j.tetasy.2010.11.025

[18] S. P. Panchgalle, H. B. Bidwai, S. P. Chavan and U. R. Kalkote, "Organocatalytic Asymmetric Synthesis of (-)$\delta$-Coniceine Based on Sequential Proline-Catalyzed Asymmetric $\alpha$-Amination-HWE Olefination," Tetrahedron: Asymmetry, Vol. 21, No. 19, 2010, pp. 2399-2401. doi:10.1016/j.tetasy.2010.08.009

[19] A. K. Sharma and R. B. Sunoj, "Enamine versus Oxazolidinone: What Controls Stereoselectivity in ProlineCatalyzed Asymmetric Aldol Reactions?" Angewandte Chemie International Edition, Vol. 49, No. 36, 2010, pp. 6373-6377. doi:10.1002/anie.201001588

[20] N. Győrffy, A. Tungler and M. Fodor, "Stereodifferentiation in Heterogeneous Catalytic Hydrogenation. Kinetic Resolution and Asymmetric Hydrogenation in the Presence of $(S)$-Proline: Catalyst-Dependent Processes," Journal of Catalysis, Vol. 270, No. 1, 2010, pp. 2-8. doi:10.1016/j.jcat.2009.10.018

[21] M. Cui, H. Song, A. Feng, Z. Wang and Q. Wang, "Asymmetric Synthesis of $(R)$-Antofine and $(R)$-Cryptopleurine via Proline-Catalyzed Sequential $\alpha$-Aminoxylation and Horner-Wadsworth-Emmons Olefination of Aldehyde," The Journal of Organic Chemistry, Vol. 75, No. 20, 2010, pp. 7018-7021. doi:10.1021/jo101510x

[22] H. Suga, T. Arikawa, K. Itoh, Y. Okumura, A. Kakehi 
and M. Shiro, "Asymmetric 1,3-Dipolar Cycloaddition Reactions of Azomethine Imines with Acrolein Catalyzed by $L$-Proline and Its Derivatives," Heterocycles, Vol. 81, No. 7, 2010, pp. 1669-1688. doi:10.3987/COM-10-11967

[23] E. Ververková, J. Štrasserová, R. Šebesta and Š. Toma, "Asymmetric Mannich Reaction Catalyzed by $N$-Arylsulfonyl-L-proline Amides," Tetrahedron: Asymmetry, Vol. 21, No. 1, 2010, pp. 58-61. doi:10.1016/j.tetasy.2009.12.013

[24] M. Lu, Y. Lu, P. K. A. Tan, Q. Y. Lau and G. Zhong, "Highly Enantioselective Synthesis of Fluorinated b-Amino Ketones via Asymmetric Organocatalytic Mannich Reactions: A Case Study of Unusual Reversal of Regioselectivity," Synlett, 2011, pp. 477-480. doi:10.1055/s-0030-1259513

[25] M .Penhoat, D. Barbry and C. Rolando, "Direct Asymmetric Aldol Reaction Co-Catalyzed by $L$-Proline and Group 12 Elements Lewis Acids in the Presence of Water," Tetrahedron Letters, Vol. 52, No. 1, 2011, pp. 159162. doi:10.1016/j.tetlet.2010.11.014

[26] A. Rai, A. K. Singh, S. Singh and L. D. S. Yadav, "Chiral Amine-Triggered Triple Cascade Reactions: A New Approach to Functionalized Decahydroquinolines," Synlett, No. 3, 2011, pp. 335-340. doi:10.1055/s-0030-1259320

[27] J. G. Hernández and E. Juaristi, “Asymmetric Aldol Reaction Organocatalyzed by $(S)$-Proline-Containing Dipeptides: Improved Stereoinduction under Solvent-Free Conditions," The Journal of Organic Chemistry, Vol. 76, No. 5, 2011, pp. 1464-1467. doi:10.1021/jo1022469

[28] D. E. Siyutkin, A. S. Kucherenko, L. L. Frolova, A. V. Kuchin and S. G. Zlotin, "2-Hydroxy-3-[(S)-prolinamido]pinanes as Novel Bifunctional Organocatalysts for Asymmetric Aldol Reactions in Aqueous Media," Tetrahedron: Asymmetry, Vol. 22, No. 12, 2011, pp. 13201324. doi:10.1016/j.tetasy.2011.07.013

[29] S. Fotaras, C. G. Kokotos, E. Tsandi and G. Kokotos, "Prolinamides Bearing Thiourea Groups as Catalysts for Asymmetric Aldol Reactions," European Journal of Organic Chemistry, Vol. 2011, No. 7, 2011, pp. 1310-1317. doi:10.1002/ejoc.201001417

[30] J. G. Hernández, V. García-López and E. Juaristi, “Solvent-Free Asymmetric Aldol Reaction Organocatalyzed by $(S)$-Proline-Containing Thiodipeptides under BallMilling Conditions," Tetrahedron, Vol. 68, No. 1, 2012, pp. 92-97. doi:10.1016/j.tet.2011.10.093

[31] M. Yamaguchi, T. Shiraishi and M. Hirama, "A Catalytic Enantioselective Michael Addition of a Simple Malonate to Prochiral $\alpha, \beta$-Unsaturated Ketoses and Aldehyde," Angewandte Chemie International Edition, Vol. 32, No. 8, 1993, pp. 1176-1178. doi:10.1002/anie.199311761

[32] M. Yasmaguchi, Y. Igarashi, R. S. Reddy, T. Shiraishi and M. Hirama, "Catalytic Asymmetric Michael Addition of Nitroalkane to Enone and Enal," Tetrahedron Letters, Vol. 35, No. 44, 1994, pp. 8233-8236. doi:10.1016/0040-4039(94)88290-8

[33] M. Yamaguchi, T. Shiraishi and M. Hirama, "Asymmetric Michael Addition of Malonate Anions to Prochiral Acceptors Catalyzed by $L$-Proline Rubidium Salt," The Journal of Organic Chemistry, Vol. 61, No. 10, 1996, pp.
3520-3530. doi:10.1021/jo960216c

[34] M. Yamaguchi, Y. Igarashi, R. S. Reddy, T. Shiraishi and M. Hirama, "Asymmetric Michael Addition of Nitroalkanes to Prochiral Acceptors Catalyzed by Proline Rubidium Salts," Tetrahedron, Vol. 53, No. 32, 1997, pp. 11223-11236. doi:10.1016/S0040-4020(97)00379-7

[35] H. Fujisawa and T. Mukaiyama, "A Catalytic Aldol Reaction between Ketene Silyl Acetals and Aldehydes Promoted by Lithium Amide under Non-Acidic Conditions," Chemistry Letters, Vol. 31, No. 2, 2002, pp. 182183. doi: $10.1246 / \mathrm{cl} .2002 .182$

[36] H. Fujisawa and T. Mukaiyama, "Lithium Pyrrolidone Catalyzed Aldol Reaction between Aldehyde and Trimethylsilyl Enolate," Chemistry Letters, Vol. 31, No. 8, 2002, pp. 858-859. doi:10.1246/cl.2002.858

[37] T. Mukaiyama H. Fujisawa and T. Nakagawa, "Lewis Base Catalyzed Aldol Reaction of Trimethylsilyl Enolates with Aldehydes," Helvetica Chimica Acta, Vol. 85, No. 12, 2002, pp. 4518-4531.doi:10.1002/hlca.200290025

[38] T. Mukaiyama, T. Nakagawa and H. Fujisawa, "Lewis Base Catalyzed Michael Reaction between Ketene Silyl Acetals and $\alpha, \beta$-Unsaturated Carbonyl Compounds," Chemistry Letters, Vol. 32, No. 1, 2003, pp. 56-57. doi:10.1246/cl.2003.56

[39] T. Nakagawa, H. Fujisawa and T. Mukaiyama, "Lithium Acetate-Catalyzed Aldol Reaction between Aldehyde and Trimethylsilyl Enolate," Chemistry Letters, Vol. 32, No. 5, 2003, pp. 462-463. doi:10.1246/c1.2003.462

[40] T. Nakagawa, H. Fujisawa and T. Mukaiyama, T. "Lithium Acetate Catalyzed Aldol Reaction between Aldehyde and Trimethylsilyl Enolate in a Dimethylformamide- $\mathrm{H}_{2} \mathrm{O}$ Solvent," Chemistry Letters, Vol. 32, No. 8, 2003, pp. 696-697. doi:10.1246/cl.2003.696

[41] T. Nakagawa, H. Fujisawa and T. Mukaiyama, "SelfPromoted Aldol Reaction between Aldehyde Having Lewis Base Moiety and Trimethylsilyl Enolate," Chemistry Letters, Vol. 33, No. 2, 2004, pp. 92-93. doi:10.1246/cl.2004.92

[42] T. Nakagawa, H. Fujisawa, Y. Nagata and T. Mukaiyama, "Lithium Acetate-Catalyzed Michael Reaction between Trimethylsilyl Enolate and $\alpha, \beta$-Unsaturated Carbonyl Compound," Chemistry Letters, Vol. 33, No. 8, 2004, pp. 1016-1017. doi:10.1246/cl.2004.1016

[43] T. Mukaiyama, T. Tozawa and H. Fujisawa, "Lithium Alkoxide-Promoted Michael Reaction between Silyl Enolates and $\alpha, \beta$-Unsaturated Carbonyl Compounds," Chemistry Letters, Vol. 33, No. 11, 2004, pp. 1410-1411. doi: $10.1246 / \mathrm{cl} .2004 .1410$

[44] E. Takahashi, H. Fujisawa, T. Yanai and T. Mukaiyama, "Lewis Base-Catalyzed Strecker-Type Reaction between Trimethylsilyl Cyanide and $N$-Tosylimines in Watercontaining DMF," Chemistry Letters, Vol. 34, No. 3, 2005, pp. 318-319. doi:10.1246/cl.2005.318

[45] Y. Sato, H. Fujisawa and T. Mukaiyama, "Lewis Base -Catalyzed [2,3]-Wittig Rearrangement of Silyl Enolates Generated from $\alpha$-Allyloxy Ketones," Chemistry Letters, Vol. 34, No. 4, 2005, pp. 588-589. doi:10.1246/cl.2005.588

[46] E. Takahashi, H. Fujisawa, T. Yanai and T. Mukaiyama, 
"Lewis Base-Catalyzed Diastereoselective Strecker-Type Reaction between Trimethylsilyl Cyanide and Chiral Sulfinimines," Chemistry Letters, Vol. 34, No. 4, 2005, pp. 604-605. doi:10.1246/cl.2005.604

[47] Y. Kawano, H. Fujisawa and T. Mukaiyama, "Lithium Acetate-Catalyzed Crossed Aldol Reaction between Aldehydes and Trimethylsilyl Enolates Generated from Other Aldehydes," Chemistry Letters, Vol. 34, No. 4, 2005, pp. 614-615. doi:10.1246/c1.2005.614

[48] Y. Kawano, N. Kaneko and T. Mukaiyama, "Lewis BaseCatalyzed Cyanomethylation of Carbonyl Compounds with (Trimethylsilyl)Acetonitrile," Chemistry Letters, Vol. 34 , No. 11, 2005, pp. 1508-1509. doi:10.1246/cl.2005.1508

[49] M. Hatano, T. Ikeno, T. Miyamoto and K. Ishihara, "Chiral Lithium Binaphtholate Aqua Complex as a Highly Effective Asymmetric Catalyst for Cyanohydrin Synthesis," Journal of the American Chemical Society, Vol. 127, No. 31, 2005, pp. 10776-10777. doi: $10.1021 / \mathrm{ja} 051125 \mathrm{c}$

[50] Y. Kawano, N. Kaneko and T. Mukaiyama, "Lewis BaseCatalyzed Perfluoroalkylation of Carbonyl Compounds and Imines with (Perfluoroalkyl)Trimethylsilane," Bulletin of the Chemical Society of Japan, Vol. 79, No. 7, 2006, pp. 1133-1145. doi:10.1246/bcsj.79.1133

[51] H. Fujisawa, E .Takahashi, T. Nagasawa and T. Mukaiyama, "Lewis Base-Catalyzed Mannich-Type Reaction between Aldimine and Trimethylsilyl Enolate," Chemistry Letters, Vol. 32, No. 11, 2003, pp. 1036-1037. doi:10.1246/cl.2003.1036

[52] E. Takahashi, H. Fujisawa and T. Mukaiyama, "Lithium Acetate-Catalyzed Mannich-Type Reaction between Trimethylsilyl Enolates and Aldimines in a Water-Containing DMF," Chemistry Letters, Vol. 33, No. 7, 2004, pp. 936-937. doi:10.1246/cl.2004.936

[53] E. Takahashi, H. Fujisawa and T. Mukaiyama, "Lewis Base-Catalyzed Anti-Selective Mannich-Type Reaction between Trimethylsilyl Enolates and Aldimines," Chemistry Letters, Vol. 34, No. 1, 2005, pp. 84-85. doi:10.1246/cl.2005.84

[54] E. Takahashi, H. Fujisawa, T. Yanai and T. Mukaiyama, "One-Pot Synthesis of $\beta$-Lactams from Aldimines and Ketene Silyl Acetals by Tandem Lewis Base-Catalyzed Mannich-Type Addition and Cyclization," Chemistry Letters, Vol. 34, No. 2, 2005, pp. 216-217. doi:10.1246/cl.2005.216

[55] H. Fujisawa, E. Takahashi and T. Mukaiyama, "Lewis Base Catalyzed Mannich-Type Reactions between Trimethylsilyl Enol Ethers and Aldimines," Chemistry-A European Journal, Vol. 12, No. 19, 2006, pp. 5082-5093. doi:10.1002/chem.200500821
[56] T. Mukaiyama, T. Kitazawa and H. Fujisawa, "A Lewis Base-Catalyzed Hetero Diels-Alder Reaction between Aldehydes and the Danishefsky's Diene," Chemistry Letters, Vol. 35, No. 3, 2006, pp. 328-329. doi:10.1246/c1.2006.328

[57] S. Hanessian and V. Pham, "Catalytic Asymmetric Conjugate Addition of Nitroalkanes to Cycloalkenones," Organic Letters, Vol. 2, No. 19, 2000, pp. 2975-2978. doi: $10.1021 / \mathrm{ol} 000170 \mathrm{~g}$

[58] S. Hanessian, Z. Shao and J. S. Warrier, "Optimization of the Catalytic Asymmetric Addition of Nitroalkanes to Cyclic Enones with Trans-4,5-methano-1-proline," Organic Letters, Vol. 8, No. 21, 2006, pp. 4787-4786. doi:10.1021/o10618407

[59] R. G. Kostyanovsky, I. M. Gella, V. I. Markov and Z. E. Samojlova, "Asymmetrical Nonbridgehead Nitrogen-IV: Chiroptical properties of the Amines, $N$-Chloroamines and Cyanamides," Tetrahedron, Vol. 30, No. 1, 1974, pp. 39-45. doi:10.1016/S0040-4020(01)97214-X

[60] T. Rosen, S. W. Fesik, D. T. W. Chu and A. G. Pernet, "Asymmetric Synthesis of 2-Substituted (4S)-4-Aminopyrrolidines. $\mathrm{S}_{\mathrm{N}} 2$ Displacement at the 4-Position of the Pyrrolidine Moiety," Synthesis, No. 1, 1988, pp. 40-44. doi:10.1055/s-1988-27459

[61] Y. N. Belokon', I. E. Zel'tzer, V. I. Bakhmutov, M. B. Saporovskaya, M. G. Ryzhov, A. I. Yanovsky, Y. T. Struchkov and V. M. Belikov, "Asymmetric Synthesis of Threonine and Partial Resolution and Retroracemization of .Alpha.-Amino Acids via Copper(II) Complexes of Their Schiff Bases with $(S)-2-N-(N '$-Benzylprolyl)aminobenzaldehyde and $(S)-2-N-\left(N^{\prime}\right.$-Benzylprolyl)amino-acetophenone. Crystal and Molecular Structure of a Copper(II) Complex of Glycine Schiff Base with $(S)-2-N-\left(N^{\prime}\right.$-benzylprolyl)aminoacetophenone," Journal of the American Chemical Society, Vol. 105, No. 7, 1983, pp. 2010-2017. doi:10.1021/ja00345a057

[62] J. Long, J. Hu, X. Shen, B. Ji and K. Ding, "Discovery of Exceptionally Efficient Catalysts for Solvent-Free Enantioselective Hetero-Diels-Alder Reaction," Journal of the American Chemical Society, Vol. 124, No. 1, 2002, pp. 10-11. doi:10.1021/ja0172518

[63] H. Furuno, T. Hayano, T. Kambara, Y. Sugimoto, T. Hanamoto, Y. Tanaka, Y. Z. Jin, T. Kagawa and J. Inanaga, "Chiral Rare Earth Organophosphates as Homogeneous Lewis Acid Catalysts for the highly enantioselective Hetero-Diels-Alder Reactions," Tetrahedron, Vol. 59, No. 52, 2003, pp. 10509-10523. doi:10.1016/j.tet.2003.06.011

[64] K. Aikawa, R. Irie and T. Katsuki, "Asymmetric HeteroDiels-Alder reaction Using Chiral Cationic Metallosalen Complexes as Catalysts," Tetrahedron, Vol. 57, No. 5, 2001, pp. 845-851. doi:10.1016/S0040-4020(00)01048-6 